\title{
Contribution to Vocabulary Learning via Mobiles
}

\author{
Saeed Khazaie (Corresponding author) \\ Islamic Azad University, Shahreza Branch \\ Postal code: 8156953999, Isfahan, Iran \\ Tel: 98-091-3186-1968Ｅ-mail: saeed.khazaie@gmail.com \\ Saeed Ketabi \\ Isfahan University, University of Isfahan \\ Tel: 98-091-3326-4035Ｅ-mail: ketabi@fgn.ui.ac.ir
}

\begin{abstract}
As mobile connectedness continues to sweep across the landscape, the value of deploying mobile technology at the service of learning and teaching seems to be both self-evident and unavoidable. To this end, this study employed multimedia to develop three types of vocabulary learning materials. Due to the importance of short-term memory in the realm of vocabulary learning, careful consideration was given to the L2 learners' different visual and verbal short-term memories. 158 L2 learners aged 18-23 participated in the major phases of vocabulary learning experiment through mobile. Based on their scores on the English Vocabulary and Recall tests and statistical analysis of the results it was revealed that L2 learners with high-visual and high-verbal abilities find it easier to learn the content presented with both pictorial and written annotations. However, L2 learners with low-visual and low-verbal abilities benefit from learning materials presented without annotations. Furthermore, delivery of learning materials with pictorial annotation to learners with high-visual ability and the delivery of learning materials with written annotation to learners with high-verbal ability result in better vocabulary learning. The findings of this study could perform as a roadmap in creating learning materials for mobile learning English language.
\end{abstract}

Keywords: Mobile learning, Multimedia learning, Short-term memory, Vocabulary learning

\section{Introduction}

Although English as an international language affects the overall competition of different fields in a country and how to enhance English proficiency of people is a critical issue in non-English countries (Chen \& Hsu, 2008), there are factors might inhibit people living in these countries from attending regular classrooms. As an instance, imagine individuals have to learn English due to their occupations or those individuals interested in traveling to countries where English is spoken as the first or second language or students learning English for studying abroad, but none of them have the opportunity for participation in classrooms. Likewise, individuals in societies have different manners and psychological barriers. An example could be a child who is filled with fear or middle-aged individuals reluctant for attending classes due to their bashfulness, especially in the time of attending classrooms and in front of their classmates. Likewise, there might be handicapped learners who are interested in learning English but they are not able to participate in common classrooms due to their disabilities. Some of such factors are represented in figure 1.

Since today's students have enormous access to digital technology display characteristics such as digital fluency and familiarity with new technologies never before imagined, they are digital natives (Prensky, 2001). With the development of technology and boom of digital revolution, foreign language teachers find it necessary to think about new effective ways to create a better foreign language teaching and learning environment that is supported by multimedia technologies.

The multimedia technology has transformed the way-students communicate, learn, and socialize themselves; improving their skills of presentation and exploitation of the knowledge (Reis, Bonacin, \& Martins, 2009). Hence, reliable, high quality audio and video delivery to user-friendly mobile devices can provide valuable and enjoyable language input to learners. Due to the specific features of multimedia in L2 development, mobile devices may open up new vistas for language learning (Godwin-Jones, 2008). As a result, mobile-assisted language learning (MALL) has become increasingly popular in the foreign language teaching and learning context.

The use of multimedia computers in education has led to the development of all sorts of instructional material in which verbal and non-verbal presentation modes are combined. Unfortunately, educational research has not yet identified how to design effective multimedia instructions (Ryu, \& Parsons, 2009). In fact there are myriad of factors that affect potential for learning from multimedia (Hede, \& Hede, 2002). Figure 2 displays Hede and Hede's model of multimedia effects on learning. As Shank (2005) stated "the model helps designers consider what factors are likely to make multimedia more or less effective for learning" (p. 6). In fact it helps to initially gain the student's 
attentions, but also-via things like digital storytelling-can illicit and can make a solid imprint of material on our long-term memories- making things easier to recall and apply later on what we need to apply this knowledge (Christian, 2010).

Likewise, Chen, Kinshuk, and Hsieh (2008) in quoting Alavi and Leidner (2001) reported that "majority of previous studies have mainly relied on the stimulus-response theory, which probed only the relationship between technology (stimulus) and learning (response). They also believed that Future studies should also take learners' characteristics like psychological learning process (PLP) into consideration" (p. 99).

Information is cognitively processed through visual and verbal channels (Jones 2004; Mayer, 1979, 2005; Paivio, 1986). The basic architecture of information processing model is the Multi-store model (Atkinson \& Shiffrin, 1968) which consists of three types of memory: Sensory, Short-Term (STM), and Long-term (LTM). Some studies have been conducted on the relation between vocabulary acquisition and verbal short-term memory (Gupta \& Mac Whinney, 1977; Greffe, Linden, Majerus, \& Poncelet, 2005).

Working memory is a more contemporary term for short-term memory which conceptualizes memory not as a passive system for temporary storage but as an active system for temporarily storing and manipulating information needed in the execution of complex cognitive tasks (e.g., learning, reasoning, and comprehension) (Richards \& Schmidt, 2002). Working memory is heavily involved in language learning (Ellis, 1996). In addition, according to Numminen (2002) working memory is an especially significant memory area for learning to read.

Therefore, the case for multimedia is based on the fact that instruction messages should be designed in the light of how human minds works (Mayer, 2005); therefore, multimedia should be translated into different types of learning materials taking related aspects and theories (i.e., cognitive theory of multimedia) into consideration.

According to the cognitive theory of multimedia learning which examines how people process separate channels for processing verbal and visual material (dual-channels assumption), each channel can process only small amount of material at a time (limited capacity assumption), and meaning learning involves engaging in appropriate cognitive processing. Figure 3 displays Mayer's cognitive theory of multimedia model.

Cognitive load theory could have many implications in the design of learning materials which must, if they are to be effective, keep cognitive load of learners at a minimum during the learning process. In essence, cognitive load theory proposes that since working memory is limited, learners may be bombarded by the information and, if the complexity of their instructional materials is not properly managed, this will result in a cognitive overload. This cognitive overload impairs the schema acquisition, later resulting in lower performance (Sweller, 1988).

Since recent approaches to mobile learning (m-learning) avoids creating pre-orchestrated pedagogical content, but allow to come up with highly modular content that can be combined as needed by teachers as well as students (Zaharieva \& Klas, 2004); developing different types of L2 learning materials to enhance vocabulary learning of learners was a concerned issue in this study.

\section{Background}

Since 2000, literature on mobile learning has been increasing more and more everyday. Many researchers from all parts of the world have been researching and still working on this new methodology (Pieri \& Diamantini, 2008). However, most of the studies relied on a qualitative method in examining the role of mobile devices in the realm of language learning and teaching. In addition, most of the studies reported the individuals' different reactions to learning in this way. Some of the studies are as follows: Pieri and Diamantini (2008) conducted a course on "training for the technology transfer managers" to meet the managers' training needs who work in an Italian Scientific Technological Park (STP). Their main activity is linked to technological transfer. In the STP the technological transfer manager is the key figure in the management of the transmission of scientific knowledge from the research world to the industrial dimension. The course addressed the blended learning model, using educational methodologies: (1) e-learning methodologies and face to face methodologies and (2) m-learning and face-to-face methodologies. Levy and Kennedy (2008) envisaged helping students take advantage of short periods of time available during the day-such as while on the bus or waiting for a class or appointment by sending regular messages in and about the language they are studying. In another study, Zaharieva and Klas (2004) proposed a model for structuring the content that allows rendering for different devices like notebooks, PDAs, and Smartphones as well as presentation of the content at different levels of details according to didactic concepts like case studies, definitions, examples, interaction, motivation, and directive.

Since software applications in the context of m-learning do not fully explore multimedia resources available at the current mobile devices Reis et al. (2009) presented a new perspective for the use of multimedia in the collaborative learning through mobile devices. 
Although a lot of studies have been conducted in this respect, there is an imperative to move from a view of e- and $\mathrm{m}$-learning as solely delivering mechanism for content because in this view the learner is just a special type of customer and the learning content is another type of e-commerce product (Hopper, Joiner, Milrad \& Sharples, 2003).

\section{Research questions}

Taking Dual Coding Theory and Cognitive Load Theory into consideration, the following questions about the delivery of learning materials with both verbal and visual annotation were addressed:

1- For EFL learners with both high-verbal and high-visual abilities (G1), will delivery of learning materials with both pictorial and verbal annotations result in better vocabulary learning than those without?

2- For EFL learners with high-visual ability but low-verbal ability (G2), will delivery of learning materials with both pictorial and written annotations results in better vocabulary learning than those without?

3- For EFL learners with both low-verbal and visual-ability (G3), will delivery of learning materials without annotations result in not significantly better vocabulary learning than those with both pictorial and written annotations?

4- For EFL learners with high-verbal ability but low-visual ability (G4), will delivery of learning materials with both pictorial and written annotations results in better vocabulary learning than those without?

\section{Hypotheses}

In line with cognitive load theory, dual coding theory and research questions four hypotheses were formulated:

Hypothesis 1 (H1): EFL learners with both high-verbal and visual ability (G1) will learn learning materials with pictorial and written annotations better than those without such annotations.

Hypothesis 2 (H2): EFL learners with high-visual ability but low-verbal ability (G2) will learn learning materials with pictorial and written annotations better than those without such annotations.

Hypothesis 3 (H3): EFL learners with both low-verbal and visual-abilities (G3) will learn not learn learning materials without annotation significantly better than those with both pictorial and written annotations.

Hypothesis 4 (H4): EFL learners with high-verbal ability but low-visual ability (G4) will learn learning materials with pictorial and written annotations better than those without such annotations.

\section{Method}

\subsection{Participants}

The participants in this experiment were selected from among those enrolled in EFL classes in an Iranian English institute. They were selected from 12 classes at the same level (i.e., pre-intermediate level). Their age range was between 19-23. Although the minimum large sample size criterion was 25 , and thus for the present study the minimum sample size of $100(25 \times 4=100)$ was sufficient, in order to enhance the result of the experiment, 158 learners were selected. Each learner had a different STM ability for processing different LCR (Learning Content Representation) types, that is; LCR with or without pictorial or written annotations (Chen, et al., 2008), therefore; STM was considered a criterion to divide learners to four groups.

Group 1 (G1): learners with higher visual and verbal abilities.

Group 2 (G2): learners with higher visual but lower verbal ability.

Group 3 (G3): learners with both lower visual and lower verbal abilities.

Group 4 (G4): learners with lower visual ability but higher verbal ability. Table 1 represents these four groups.

\subsection{Materials}

The materials used in this study were: a) proficiency test, b) vocabulary level test, c) a background questionnaire, d) software, e) visual and verbal STM tests, and f) recognition and recall tests.

First, to make sure that the participants were all of the same level of proficiency, they were arranged to participate in Nelson English language test 150 D. The Nelson English language test consists of four types of tests which are equivalent in difficulty. The levels are numbered 050 up to 500, in which, test $150 \mathrm{D}$ seems suitable for proving the fact that learners were in pre-intermediate level. Its reliability was calculated through KR-21, and it was .82. The validity was also confirmed by three competent experts in this field.

In order to specify the words for the third phase of the experiment (i.e., learning phase), the word frequency method was adopted. According to Nation and Waring (1997), there should be a clear and sensible goal for vocabulary 
learning. Frequency information provides a rational basis for making sure that learners get the best return for their vocabulary learning effort. Vocabulary learning frequency lists which take account of range have an important role to play in curriculum design and in setting learning goals.

Regarding vocabulary level test, a vocabulary level test of 50 words was administered to assess learners' original knowledge of words and to prevent the inclusion of words which learners were familiar with in the learning phase of the experiment. The words for the vocabulary level test were selected from Bauman's General Service List (GSL) which consists of 2284 words. One word from every 40 words was selected, starting from the $40^{\text {th }}$ word $(402203$ more) to $2000^{\text {th }}$ word (15 2000 scenery) (See appendix A). The Bauman's GSL is based on the Brown's corpus which contains 1000,000 words in Bauman's GSL. Beside every word there are two numbers, the first one indicates the order of the word on the list made the frequency of words in Brown's corpus and the other number indicates the frequency of occurrence of the word in Brown's corpus. Since interchange books (Hully \& Richards, 2005) are taught in this language institute, the vocabulary lists at the end of the yellow and red interchange books (i.e., introductory and pre-intermediate books) were checked too; to discourage the application of words which learners have already learned from these books. When learners completed the vocabulary level test it was cleared that nearly all the learners were familiar with words up to the word 'absolute' (1280 62 absolute). Therefore, 20 words for third phase of learning were selected from $1500^{\text {th }}$ 'wisdom' onward, randomly (See appendix B). For each word, the following two types of representation were made:

Type 1- represents the English word, its pronunciation, part of speech and the Persian meaning of the word.

Type 2- represents the materials shown in type 1 plus the pictorial and written annotations.

Examples of two different representation types, for the word 'explode' are shown in figure 4. To enhance the result, all the sentences for type 2 were selected from Longman Dictionary of Contemporary English.

With regard to the background questionnaire, an open-ended questionnaire was prepared to make it possible for learners to express their thoughts and ideas without limitation. The questions in this questionnaire were those ones which help the researchers in conducting the subsequent phases of the study. The validity of the questionnaire was confirmed by psychologists and sociologists (See appendix C).

As far as the software was concerned, it was designed for the conduction of the main phases of the study. Installation procedure, the different parts, and hoe to use it all described in a separate manual with the CD of the software.

Concerning visual and verbal STM abilities, 40 questions were prepared to test the learners' visual and verbal ability, that is; 20 questions were prepared for testing the visual ability and 20 questions for testing the verbal abilities. The reliability of visual and verbal STM was calculated through Crobach's alpha and it was .87.

Finally, due to the fact that recognition and recall tests are often used to examine learner's vocabulary knowledge (Jones, 2004), 20 recognition questions and 20 recall questions were prepared for testing the learners' vocabulary learning. Their internal consistency reliability was calculated through Crobach's alpha and it was .81.

\subsection{Procedure}

The main procedure for this study consisting four phases took place in the language laboratory of the institute.

Phase I: Introduction. In this phase, all the details and objectives of the experiment were explained. Then, the background questionnaire was distributed among to learners to complete.

Phase II: STM ability test. Each learner was assigned a computer for STM test. First, they took part in a visual STM ability test. Then, they participated in verbal STM test. Each question in these two tests (i.e., verbal and visual) comprised two subparts. Regarding the visual section of the test initially a picture was displayed for 08.00 seconds; then a question was asked about the pictures. The learners were given 06.00 seconds to answer the question. Concerning the verbal test, first, a sentence was displayed for 08.00 seconds then a question addressing the sentence were asked; the learners had to answer in 06.00 (see appendix E).Afterwards, each learner's answers were recorded with two types of score (i.e., raw score and standard score with a mean of 0 and standard deviation 1 ). On the basis of their z scores of visual and verbal STM abilities, participants were divided into four groups, with 55 in group 1 (G1), 30 in group 2 (G2), 42 in group 3 (G3) and 31 in group 4 (G4). In other words, if participants' visual z scores were higher than zero they were put into group 1 or group 2 , if their visual $\mathrm{z}$ scores were lower than 0 they were put into group 3 or 4. Likewise, if participants' verbal z scores were more than 0 they were put into group 1 or group 4 and if their verbal $\mathrm{z}$ scores were lower than 0 they were put into group 2 or group 3 . In fact the cut-off score for division of participants into four groups was the 0 of $z$ score. 
Phase III: Learning new vocabulary items. In this phase, every participant was assigned a mini-laptop to learn 20 new English vocabulary items. All vocabulary items were sent to their mini-laptops via Bluetooth. Each item was presented to learners for about 120 seconds. Since the learners were not able to exit the program from the time they opened the target files until they ended the program; the researchers had full control on all the mini-laptops.

In order to counterbalance the effect of the order of representation, a $2 \times 2$ Latin Square (LS) design was used. According to Montgomery (1991), one of the frequent uses of LS is to counterbalance the various sequences in which the level of an independent variable might take place. In LS, each of the 2 digits (i.e., 1 \& 2) would appear just once in each row and column. Figure 5 shows a $2 \times 2$ Latin Square.

In this research project, the first 10 words were delivered to first participant in type 1 and the last 10 words in type 2. At the same time, the second participant received the first 10 words in type 2, and the last 10 words in type 1 .

Phase IV: Testing phase. After the third phase (i.e., learning phase), learners took part in EVRR (English vocabulary recognition and recall) tests. First, they took part in recognition tests which consisted of 20 multiple-choice questions and then they participated in the recall tests which consisted of 20 questions, too (See appendix E). The framework of making recognition and recall questions were the ones extracted from the study which was done by Chen et al. (2008).

\section{Results and discussion}

According to Tables 2 the results of the four hypotheses are as follows.

As Table 2 and hypothesis 1 represents, recognition scores of type 2 learning materials were higher than the those of type 1 learning materials for learners in $\mathrm{G} 1(\mathrm{p}=0.000)$. Recall scores of type 2 learning materials were higher than those of type 1 learning materials for learners in $\mathrm{G} 1(\mathrm{p}=0.000)$. In addition, the average score of type 2 learning materials was higher than those of type 1 learning materials $(p=0.000)$. Hypothesis 1 was not rejected. This implies that learners with high-verbal and high-visual abilities learn learning materials with both pictorial and written annotations better than those without such annotations.

According to Table 2 and Hypothesis 2, recognition scores of type 2 learning materials were higher than the those of type 1 for learners in $\mathrm{G} 2(\mathrm{p}=0.000)$. Recall scores of type 2 learning materials were higher than those of type 1 learning materials for learners in $\mathrm{G} 2(\mathrm{p}=0.001)$. Also, the average score of type 2 learning materials were higher than the average score of type 1 learning materials $(\mathrm{p}=0.000)$. Hence, hypothesis 2 was not rejected. This implies that learners with high-visual ability but low-verbal ability learn vocabulary learning materials with both pictorial and written annotations better than those without such annotations.

Regarding to hypothesis 3 and as Table 2 represents, recognition scores of type 1 materials were higher than those of type 2 learning materials for learners in $\mathrm{G} 3(\mathrm{p}=0.000)$. Recall scores of type 1 learning materials were higher than those of type 2 learning materials for learners who were in $\mathrm{G} 3(\mathrm{p}=0.000)$. Likewise, the average score of type 1 learning materials were higher than the average score of type 2 learning materials for learners in $\mathrm{G} 3(\mathrm{p}=0.000)$. Thus, hypothesis 3 was rejected. This implies that for learners with both low-visual and low-verbal abilities learning materials without annotation result in better vocabulary learning.

Concerning hypothesis 4 and Table 2, the recognition scores of type 2 learning materials obtained by learners placed in $\mathrm{G} 4$ were higher than those of type $1(\mathrm{p}=0.000)$. Also, as Table 2 displays, recall scores of type 2 learning materials were higher than recall scores of type 1 learning materials for learners who were in $\mathrm{G} 4(\mathrm{p}=0.000)$. Also, the average score of type 2 learning materials were higher than the average scores of type 1 learning materials $(\mathrm{p}=0.000)$. Hypothesis 4 was not rejected. This implies that learners with high-verbal ability but low-visual ability learn those vocabulary items which are delivered to them with both written and pictorial annotations better than those items which are delivered without such annotations.

\section{Conclusions and Implications}

Based on the hypotheses, the following points can be inferred:

- $\quad$ Learners with both high-visual and high-verbal ability, learn learning materials with written or pictorial annotation better than materials without such annotations.

- Delivery of learning materials with pictorial annotation to learners with both high-visual but low-verbal ability results in better vocabulary learning.

- Delivery of learning materials without annotation to learners with both low-visual and low-verbal abilities results in better vocabulary learning than delivery of types with pictorial or written annotation. 
- Learners with low-visual but high-verbal ability learn learning materials with written annotation better than those without such annotation.

Also, the results of the study support the results reported by Chen et al. (2008), where it was demonstrated that learners with high-verbal and high-visual ability learn learning materials with pictorial or written annotation better. On the other hand, with both low-visual and low-verbal abilities don't benefit from learning materials with pictorial or written annotation. According to this study, although learners with good visual ability but low verbal ability act well in recognition, they do not perform well on recall tests. Likewise, the same result is true for learners with high-verbal but low-visual ability and learning materials with written annotation.

Regarding the potential of mobiles in the realm of teaching and learning vocabulary it seems necessary to go beyond and apply them in teaching and learning other skills and sub-skills. Although in this study such matters as the level of the participants and their PLP were taken into consideration, there were still a lot of issues, theories, and rules that could not be ignored.

However, a major limitation in the application of mobile for EFL learning is that in the early phases it can not replace the common daily classes and demands the proper conditions that at times must be met to set so that the ground for their implementation; on the other hands, at the primary phases they could be exploited to support the learners' out-of-class practice (Kennedy \& Levy, 2008).

For further study, thanks to the existence of Internet connection facilities such as GPRS and Wi-Fi, it seems suitable to go beyond using SMS, MMS, and Bluetooth.

\section{References}

Atkinson, R. C., \& Shiffrin, R. M. (1968). Human memory: A proposed system and its control processes. In K.W. Spence \& J.T. Spence (Eds.), The Psychology of Learning and Motivation, 2, 89-195.

Bauman (1995). About the GSL. Retrieved March 20, 2009 from http://www.jbauman.com/aboutgsl.html

Brown, J. D. (1988). Understanding research in second language learning. NY: Cambridge University Press.

Bull, S., \& Kukulska - Hulme, A. (2009). Theory- based support for mobile language learning: Noticing and recording. iJIM, 3(2), 12-18.

Chen, Ch.-M., \& Chung, Ch.-J. (2008). Personalized mobile English Vocabulary learning system based on item -response theory and learning memory cycle [Abstract]. Journal of Computer and Education, 51 (2), 624-645.

Chen, Ch.-M., \& Hsu, sh.-H. (2008). Personalized mobile learning system for supportive effective English learning. Educational Technology and Society, 11 (3), 153-180.

Chen, N.-S., Hsieh, sh.-W., \& Kinshuk (2008). The effects of short-term memory and content representation type on mobile language learning. Journal of Learning and Technology, 12, 93-113. Christian, D. S. (2010). In cognitive psychology, learning styles, learning theories, multimedia, pedagogy. [Online] Available: http://danielschristian.com/learning-ecosystems/2010/04/30/ the-value-of-multimedia (March 30, 2010)

Chun, D., M., \& Plass, J. L. (1996). Effects of multimedia annotations on vocabulary acquisition [Abstract]. The Modern Language Journal, 80, 183-198.

Coe, N., \& Fowler, W. S. (1976). Nelson English Language Tests. London: Butler and Tanner Ltd.

Conacher, J. (2009). November). Using technologies in learning, teaching and research: Challenges and opportunities for the language Profession. Paper presented at the conference of Technology Enhanced Language Teaching and Learning, London, Vernon.

Cui, G., \& Wang, Sh. (2008). Adopting cell phones in EFL teaching and learning. Journal of Educational Technology Development and Exchange, 1, 69-80.

Diagram of factors inhibiting people attending regular classrooms. (2010).Retrieved July1, 2010 from http:// www.Amozeshyar.com

Ellis, N. C. (1996). Working memory in the acquisition of vocabulary and syntax: putting language in good order. The Quarterly Journal of Experimental Psychology, 49(1), 234-250.

Entekhabi, N., Haghshenas, A. M., \& Samei, H. (2003). Millennium English-Persian dictionary. Tehran: Farhang Moaser Publishers.

Fang, L. (2010). Using multimedia to motivate students' interest in English languagelearning. Unpublished master's thesis, University of Wisconsin-Platteville, Wisconsin. Godwin-Jones, R. (2008). Emerging technologies, Mobile-computing trends: Lighter, Faster, \& Smarter. Language Learning and Technology, 12(3), 3-9. 
Greffe, Ch., Linden, M. V., Majerus, S., \& Poncelet, M. (2005). Relations between Vocabulary development and verbal short - term memory: The relative importance of short-term memory for serial order and item information. Journal of Experimental Child Psychology, 93 (2), 95-119.

Gupta, P., \& Whinney, B. M. (1997). Vocabulary acquisition and verbal short-term memory: computational and neural bases. Brain and Language, 59, 267-333.

Hede, T. \& Hede, A. (2002). Multimedia effects on learning: Design implications of an integrated model. Paper presented at the ASET conference, Melbourne, Australia.

History of mobile phone, (n.d.). Retrieved March 10, 2010 from:

http://www.phonhistory.co.uk/mobile-phones-history.html

Hopper, H.U., Joiner, R., Milrad, M., \& Shrples, M. (2003). Guest editorial: wireless and mobile technology in education. Journal of Computer Assisted Learning, (19), 255-259.

Hully, J., Proctor, S., \& Richards, J. C., (2005). New Interchange (3rd ed.). UK: Cambridge University Press.

Jones, L., (2004). Testing L2 vocabulary recognition and recall. Learning and Technology, 8(3), 122-143.

Longman dictionary of contemporary English ( $4^{\text {th }}$ ed.). England: Pearson Education Limited.

Kennedy, C., \& Levy, M. (2008). Using SMS to support beginners' language learning. Recall,20 (3), 315-330.

Klas, W., \& Zaharieva, M. (2004). Mobilearn: An open approach for structuring content for mobile learning environments (pp. 114-124). Berlin: Springer.

Mayer, R.E., 1979. Can advance organizers influence meaningful learning? Review of Educational Research, 49(2), 371-383.

Mayer R.E. (2003). Elements of a science of e-learning. Educational Computing Research, 29 (3), 297-313.

Mayer, R. E., Sobko, K., \& Mautone, P.D. (2003). Social Cues in multimedia learning: Role of Speaker's Voice. Journal of Educational Psychology, 95, 419-425.

Mayer, R. E. (Ed.) (2005). The Cambridge handbook of multimedia learning. Cambridge University Press.

Rate of influencing cell phones will reach to 61 percent at the end of the year 2008. Retrieved February 12, 2010 from http: //www.medianews.ir

Montgomery, D. C. (1991). Design and analysis of the experiments. NY: John Wiley \& Sons.

Nation, P., \& Waring, R. (1997). Vocabulary size, text coverage and word lists. Retrieved March 27, 2010, fromhttp://www.fltr.ucl.ac.be./fltr/GERM/ETAN/bibs/vocab/cup.html

Paivio, A. (1986). Mental representations: A dual coding approach. UK: Oxford University Press.

Pieri, M., \& Diamantini, D. (2008).from E-learning to Mobile learning: New opportunities. International Journal of Knowledge and Learning, 4 (2-3), 176-188.

Prensky, M. (2001). Digital Natives, Digital Immigrants. On the Horizon, 9(5), 1-6.

Richards, J. C., \& Schmidt, R. (2002). Dictionary of language and applied linguistics ( $3^{\text {rd }}$ ed.). England: A Pearson Education Book.

Reis, J. C., Bonacian, R., \& Martins, M. C. (n.d.). Using multimedia in the mobile collaborative learning. Research, Reflection, and Innovation in Integrating ICT in Education, 869-873.

Shank, P. (2005). The value of multimedia in learning. Adobe's Media Center.

Sharples, M. (2000). The design of personal mobile technologies for lifelong learning. Computer and Education, 34 (4), 177-193.

Sweller, J. (1988) Cognitive load during Problem Solving: Effects on learning. Cognitive Science, 12, 257-285.

Traxler, J. (2007). Defining, Discussing, and Evaluating Mobile Learning. International Review of Research in Open and Distance Learning, 8(2), 1-12.

United Nations [UN], 2010. 67 Percent of people have cell phones. Retrieved March 25, 2010 from http://www.stltoday.com/stltoday/news/stories.nfs/world/story. 
Table 1. Four groups of learners based on their visual and verbal abilities

\begin{tabular}{l|l} 
G2 & \multicolumn{1}{c}{ G1 } \\
High visual ability & $\begin{array}{l}\text { High verbal ability } \\
\text { High visual ability }\end{array}$ \\
\hline Low verbal ability & High verbal ability \\
Low visual ability & Low visual ability \\
G3 & \multicolumn{1}{|c}{ G4 }
\end{tabular}

Table 2. Descriptive statistics: Recognition score, Recall score, \& Average score of Four Groups

\begin{tabular}{|c|c|c|c|c|c|c|c|c|c|}
\hline \multirow{2}{*}{ Group } & \multirow{2}{*}{ Number of subjects } & \multirow{2}{*}{ Age } & \multirow{2}{*}{ Type } & \multicolumn{2}{|c|}{ Recognition Score } & \multicolumn{2}{|c|}{ Recall Score } & \multicolumn{2}{|c|}{ Average Score } \\
\hline & & & & Mean & Std. Error & Mean & Std. Error & Mean & Std. Error \\
\hline \multirow{2}{*}{1} & \multirow{2}{*}{55} & \multirow{2}{*}{20.509} & 1 & 2.31 & 0.158 & 1.02 & 0.123 & 1.6636 & 0.11463 \\
\hline & & & 2 & 4.04 & 0.119 & 3.25 & 0.125 & 3.6455 & 0.10107 \\
\hline \multirow{2}{*}{2} & \multirow{2}{*}{30} & \multirow{2}{*}{20.766} & 1 & 2.31 & 0.158 & 1.02 & 0.123 & 1.2500 & 0.10920 \\
\hline & & & 2 & 4.04 & 0.119 & 3.25 & 0.125 & 2.2333 & 0.14726 \\
\hline \multirow{2}{*}{3} & \multirow{2}{*}{42} & \multirow{2}{*}{20.714} & 1 & 3.38 & 0.199 & 2.27 & 0.204 & 2.8214 & 0.17362 \\
\hline & & & 2 & 1.52 & 0.149 & 0.90 & 0.120 & 1.2143 & 0.10796 \\
\hline \multirow{2}{*}{4} & \multirow{2}{*}{31} & \multirow{2}{*}{20.838} & 1 & 2.06 & 0.153 & 0.97 & 0.150 & 1.5161 & 0.11236 \\
\hline & & & 2 & 3.68 & 0.156 & 2.77 & 0.165 & 3.2258 & 0.13686 \\
\hline
\end{tabular}

Table 3. Results of the Four Hypotheses

\begin{tabular}{|c|c|c|c|}
\hline Average Score of Recognition and Recall Tests & Recall Score & Recognition Score & Hypothesis \\
\hline $2>1(\mathrm{p} .=0.000)^{*}$ & $2>1(\mathrm{p} .=0.000)^{*}$ & $2>1(\mathrm{p} .=0.000)^{*}$ & \multirow{2}{*}{$\begin{array}{l}\text { Hypothesis } 1 \\
\text { Require } 2>1\end{array}$} \\
\hline Not Rejected & Not Rejected & Not Rejected & \\
\hline $2>1(\mathrm{p} .=0.000)^{*}$ & $2>1(\mathrm{p} .=0.000)^{*}$ & $2>1(\mathrm{p} .=0.000)^{*}$ & \multirow{2}{*}{$\begin{array}{c}\text { Hypothesis } 2 \\
\text { Require } 2>1\end{array}$} \\
\hline Not Rejected & Not Rejected & Not Rejected & \\
\hline $2=1(\mathrm{p} .=0.000)$ & $2=1(\mathrm{p} .=0.000)$ & $2=1(\mathrm{p} .=0.000)$ & \multirow{2}{*}{$\begin{array}{l}\text { Hypothesis } 3 \\
\text { Require } 1 \text { not }>2\end{array}$} \\
\hline Rejected & Rejected & Rejected & \\
\hline $2>1(\mathrm{p} .=0.000)$ & $2>1(\mathrm{p} .=0.000)$ & $2>1(\mathrm{p} .=0.000)$ & \multirow{2}{*}{$\begin{array}{c}\text { Hypothesis } 4 \\
\text { Require } 2>1\end{array}$} \\
\hline Not Rejected & Not Rejected & Not Rejected & \\
\hline
\end{tabular}

Note. $1 \& 2$ refer to the type of learning materials.

${ }^{*} P<0.05$

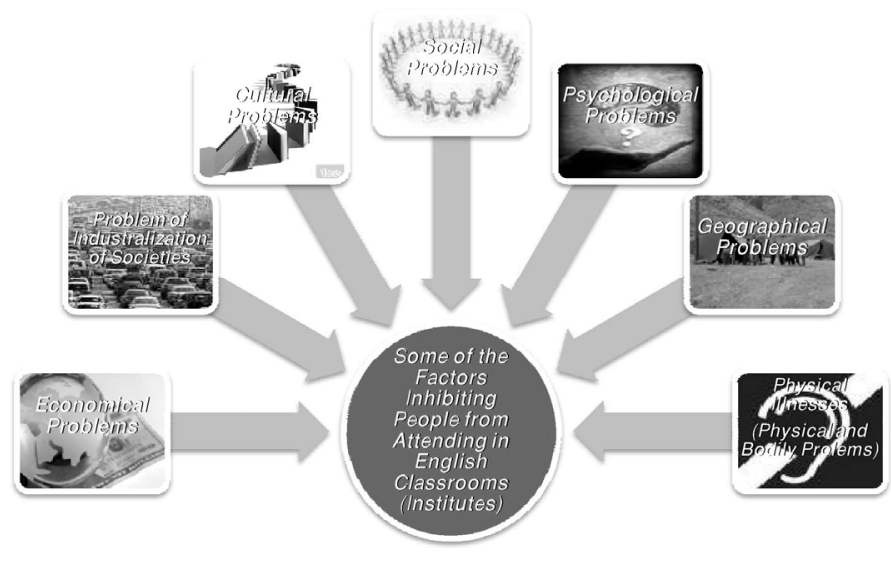

Figure 1. Factors Inhibiting People from Attending Regular Classrooms ("Amozeshyar," 2010) 


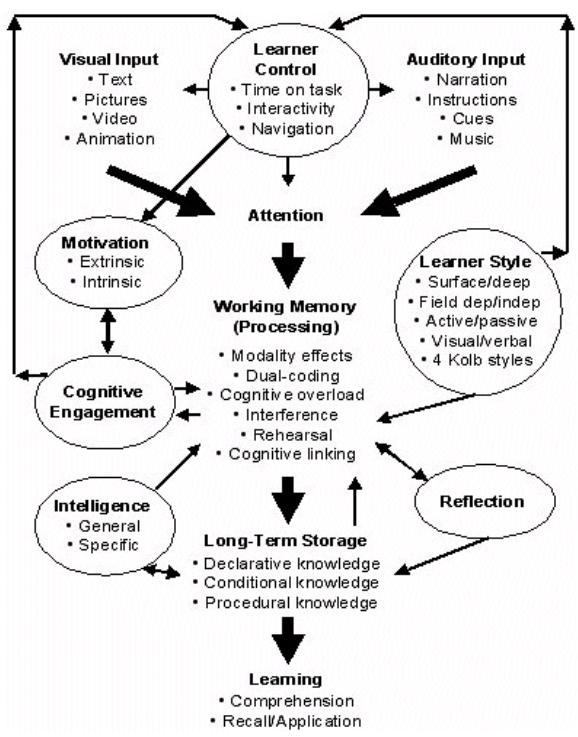

Figure 2. Hede and Hede's (2002) Model of Multimedia Effects on Learning (p. 6)

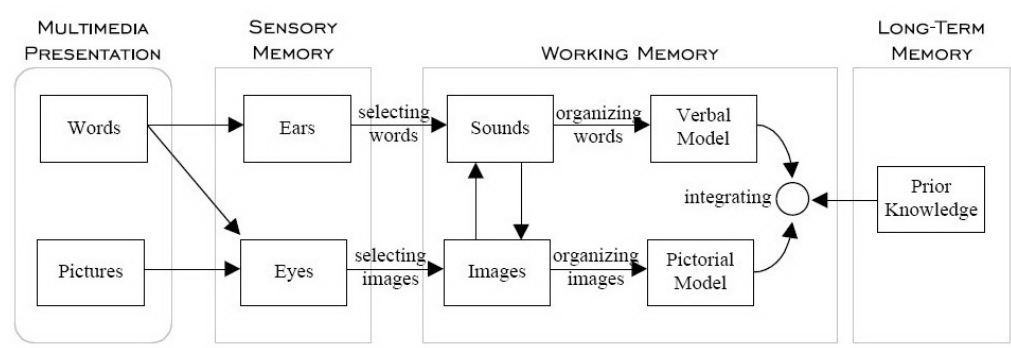

Figure 3. Mayer's cognitive theory of multimedia model (Mayer, 2005, p. 54)

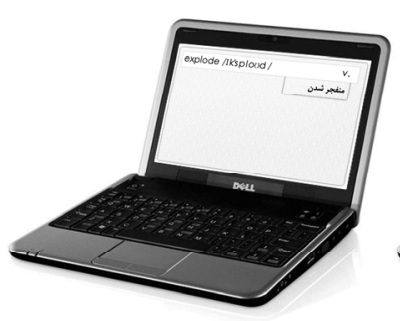

Type 1

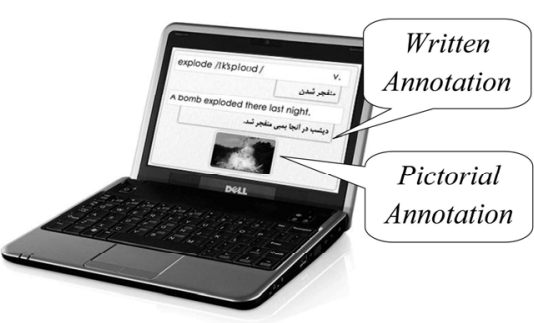

Type 2

Figure 4. Different types of representation

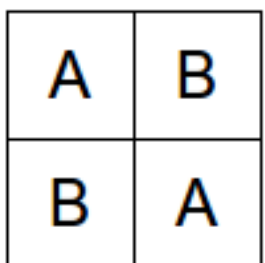

Figure 5 .The $2 \times 2$ Latinsquare 


\section{Appendix A - Vocabulary level test}

\begin{tabular}{|c|c|c|c|c|c|}
\hline \multicolumn{6}{|c|}{ Basic English Vocabulary Test } \\
\hline $\begin{array}{l}\text { Write down the } \\
\text { Persian meaning if } \\
\text { you know this word }\end{array}$ & $\begin{array}{l}\text { Mark 'X' if you don't } \\
\text { know the meaning of } \\
\text { this word }\end{array}$ & $\begin{array}{l}\text { English } \\
\text { words }\end{array}$ & $\begin{array}{l}\text { Write down the } \\
\text { Persian meaning if } \\
\text { you know this word }\end{array}$ & $\begin{array}{l}\text { Mark 'X' if you don't } \\
\text { know the meaning of } \\
\text { this word }\end{array}$ & $\begin{array}{l}\text { English } \\
\text { words }\end{array}$ \\
\hline & & Invite & & & more \\
\hline & & Seed & & & find \\
\hline & & Guide & & & write \\
\hline & & Snow & & & home \\
\hline & & passage & & & line \\
\hline & & Brain & & & repot \\
\hline & & absolute & & & direct \\
\hline & & Afford & & & body \\
\hline & & Noise & & & thus \\
\hline & & Solve & & & death \\
\hline & & Burst & & & road \\
\hline & & interference & & & modem \\
\hline & & fortunate & & & island \\
\hline & & Coal & & & English \\
\hline & & Insect & & & employ \\
\hline & & Sugar & & & opportunity \\
\hline & & convenient & & & touch \\
\hline & & Crown & & & current \\
\hline & & companion & & & progress \\
\hline & & destructive & & & burn \\
\hline & & Bunch & & & engineer \\
\hline & & Resign & & & shoulder \\
\hline & & Wreck & & & destroy \\
\hline & & essence & & & stick \\
\hline & & scenery & & & admit \\
\hline
\end{tabular}

Appendix B - selected 20 vocabulary items for the third phase

\begin{tabular}{|c|c|c|c|}
\hline Order & Frequency & Word & Part of speech \\
\hline 1516 & 43 & anxiety & n. \\
\hline 1519 & 42 & sacred & Adj. \\
\hline 1583 & 38 & flame & n. \\
\hline 1628 & 35 & adventure & n. \\
\hline 1638 & 35 & melt & v. \\
\hline 1641 & 35 & bury & v. \\
\hline 1797 & 26 & immense & Adj. \\
\hline 1812 & 25 & feather & n. \\
\hline 1840 & 23 & bunch & n. \\
\hline 1855 & 23 & decay & v. \\
\hline 1875 & 22 & explode & v. \\
\hline 1929 & 19 & hut & n. \\
\hline 2061 & 12 & patriotic & Adj. \\
\hline 2080 & 12 & castle & n. \\
\hline 2101 & 11 & applaud & v. \\
\hline 2119 & 10 & beast & n. \\
\hline 2192 & 7 & paw & n. \\
\hline 2198 & 6 & bribe & v. \\
\hline 2278 & 0 & oar & n. \\
\hline 2283 & 0 & beak & n. \\
\hline
\end{tabular}




\section{Appendix C - Sample of questionnaire}

In the name of God

First name:

Last name:

Age: code: .......

How long have you used mobile phone?

How much do you use your mobile phone during a day?

How much do you tend to use mobile phone for learning English?

What is your opinion about the future of using mobile phone in learning English?

\section{Appendix D - Sample of visual and verbal STM tests}
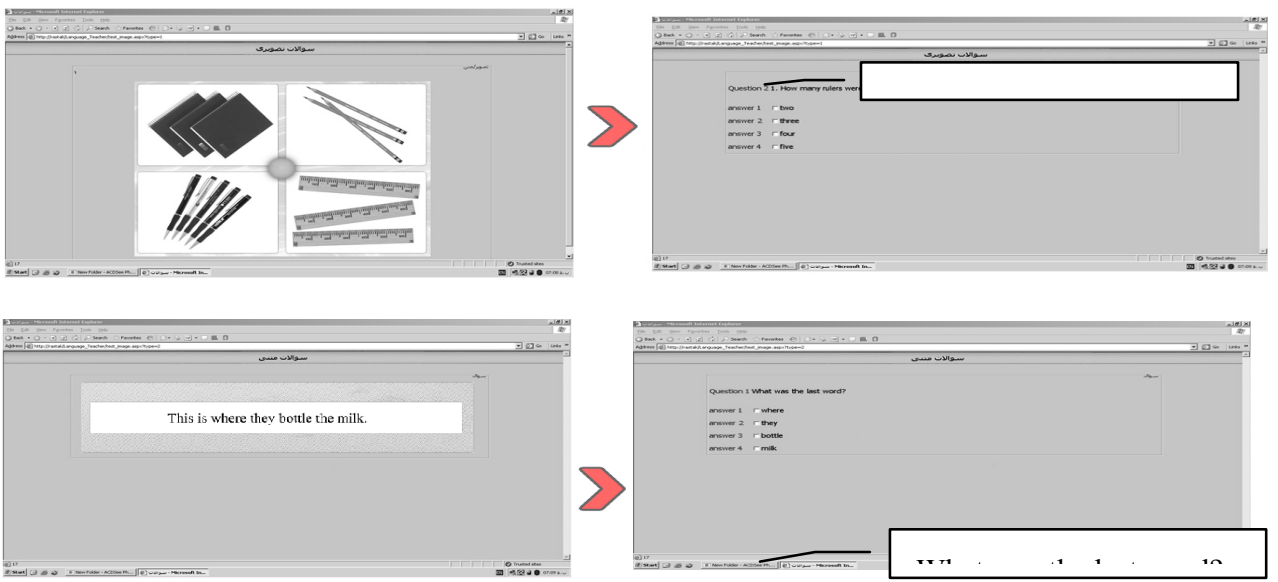

Appendix E - Samples of Recall and Recognition Question

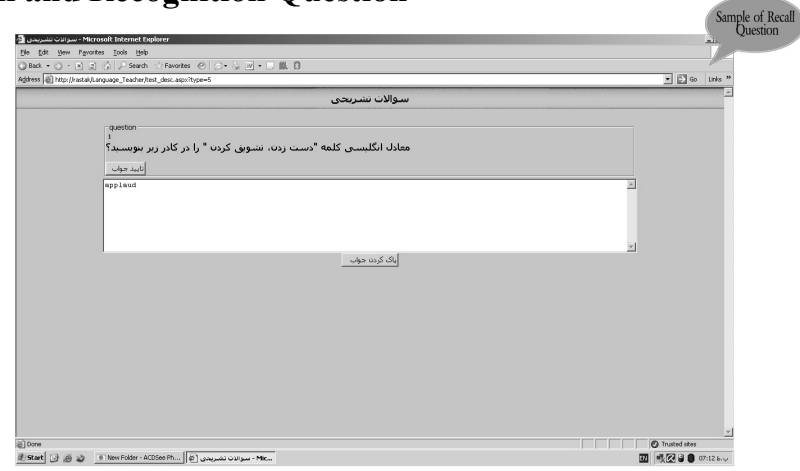

